\title{
Index of first lines
}

$\begin{array}{ll}\text { A company of poets strove to buy } & \text { 2I8 }\end{array}$

Ah! Why doth death its latest stroke delay 28I

Alas, dear Mother, fairest queen and best, $\quad 47$

Alas, poor Castle, how great is thy change 23I

Alas, slain is the head of Israel, $\quad 74$

Alas! Who shall my funeral mourner be, $\quad 248$

$\begin{array}{ll}\text { All sorts of men through various labours press } & \text { 3I4 }\end{array}$

$\begin{array}{ll}\text { All you that have indulgent parents been, } & \text { I08 }\end{array}$

$\begin{array}{ll}\text { Although, great Queen, thou now in silence lie, } & 69\end{array}$

$\begin{array}{ll}\text { Although the most do with officious heat } & \text { I84 }\end{array}$

Amongst the happy wits this age hath shown, 65

$\begin{array}{ll}\text { An earring may well a zodiac be, } & 2 \text { I6 }\end{array}$

As loving hind that (hartless) wants her deer $\quad 86$

As, when the first day dawned, man's greedy eye $\quad$ I86

$\begin{array}{ll}\text { As when the glorious magazine of light } & \text { I73 }\end{array}$

As the triumphant sounds and shows 293

Attend then my discourse, wherein a new $\quad 257$

Be kind, my dear Rosania, though 'tis true I7 I

Betwixt two ridges of ploughed land sat Wat, $\quad 234$

$\begin{array}{ll}\text { Bright day star look not in at me; } & 280\end{array}$

$\begin{array}{ll}\text { Come, my Ardelia, to this bower } & \text { I54 }\end{array}$

$\begin{array}{ll}\text { Come, my dear children, to this lonely place } & \text { I27 }\end{array}$

Come, my Lucasia, since we see $\quad$ I56

Content, the false world's best disguise, $\quad$ I58

$\begin{array}{ll}\text { Could we the several motions of life know, } & 2 \mathrm{I} 3\end{array}$

Dear daughters come make haste away, $\quad 92$

Dear God turn not away thy face, $\quad$ I22

Fair Venus, mother of Aeneas' race, 25I

Farewell dear babe, my heart's too much content, 88 


\section{Index of first lines}

Give me a free and noble style, that goes

Hasten, great prince, unto thy British Isles,

$\begin{array}{ll}\text { Heaven's glorious eye, which all the world surveys, } & 283\end{array}$

Her corpse was borne to church on grey goose wing, 209

How sacred and how innocent $\quad 190$

$\begin{array}{ll}\text { How vain a thing is man, whose noblest part, } & \text { I67 }\end{array}$

If every thing hath sense and reason, then 202

In secret place where once I stood, $\quad 80$

In sighs and tears there is no end; $12 \mathrm{I}$

Is Lisle and Lucas slain? O say not so! $\quad$ I04

$\begin{array}{ll}\text { It is most strange, } & 223\end{array}$

$\begin{array}{ll}\text { I think not on the state, nor am concerned } & \text { I77 }\end{array}$

I write, and write, and't may be never read; $\quad 206$

Late in an evening as I walked alone, $\quad 99$

$\begin{array}{ll}\text { Leave off, you pitying friends, leave off; in vain } & 277\end{array}$

$\begin{array}{ll}\text { Let none presume to weep: tears are too weak, } & \text { II7 }\end{array}$

Let none sigh more for Lucas or for Lisle, $\quad$ II8

Most of our modern writers nowadays, $\quad 244$

$\begin{array}{ll}\text { Must I be still confined to this sad grove } & \text { I29 }\end{array}$

Must I thus ever interdicted be? I3I

Must then my crimes become his scandal too? I88

$\begin{array}{ll}\text { My dear Antenor now give o'er, } & 197\end{array}$

My head, my heart, mine eyes, my life, nay more, $\quad 84$

$\begin{array}{ll}\text { My love, life, crown, peace, treasure, joys were lost } & 287\end{array}$

$\begin{array}{ll}\text { My ravished soul a pious ardour fires } & 299\end{array}$

Noah and his sons gladly God's promise heard 3 IO

No, no, unfaithful world, thou hast $\quad$ I93

Now to whatever thoughts men's minds are tied, 262

O that the tears that trickle from mine eyes I40

Poor desolate garden, smile no more on me 285

$\begin{array}{ll}\text { Reading my verses, I liked them so well, } & \text { 210 }\end{array}$

Sir, / Extremely I deplore your loss; $\quad$ I37

$\begin{array}{ll}\text { Small atoms of themselves a world may make, } & 212\end{array}$

$\begin{array}{ll}\text { So clear a season, and so snatched from storms, } & \text { I83 }\end{array}$

$\begin{array}{ll}\text { Some think the world would fall, and not hang so, } & \text { 2I4 }\end{array}$

Tell me no more her hair was lovely brown, $\quad$ II3

The hearts thus intermixed speak I6I

$\begin{array}{ll}\text { The hunted hart when she begins to tire, } & \text { I47 }\end{array}$

$\begin{array}{ll}\text { There is an arch i'the middle of the face } & 305\end{array}$ 


\section{Index of first lines}

$\begin{array}{ll}\text { There was an island rich by nature's grace, } & 238\end{array}$

$\begin{array}{ll}\text { The shepherdesses which great flocks do keep } & 245\end{array}$

This island lived in peace full many a day 24I

$\begin{array}{ll}\text { Those that the hidden chemic art profess } & \text { I24 }\end{array}$

$\begin{array}{ll}\text { Though it be just to grieve when I must part } & \text { I52 }\end{array}$

Thou ill-formed offspring of my feeble brain, $\quad 83$

To sing of wars, of captains, and of kings, 32

$\begin{array}{lr}\text { Twice forty months in wedlock I did stay, } & \text { I98 }\end{array}$

$\begin{array}{ll}\text { Victorious palm, triumphing laurel boughs } & \text { I25 }\end{array}$

$\begin{array}{ll}\text { Virtue once in the Olympics fought a duel, } & \text { I42 }\end{array}$

$\begin{array}{ll}\text { We falsely think it due unto our friends } & \text { I64 }\end{array}$

We find that in th'East Indies stars there be, 215

$\begin{array}{ll}\text { What on earth deserves our trust? } & \text { I96 }\end{array}$

When England did enjoy her halcyon days, [I650] 59

When England did enjoy her halcyon days, [1678] 76

$\begin{array}{ll}\text { When God, contracted to humanity, } & \text { I75 }\end{array}$

When time was young, and world in infancy, 34

$\begin{array}{ll}\text { Whilst with a smooth but yet a servile tongue } & 268\end{array}$

$\begin{array}{ll}\text { Who can but pity this poor turtle-dove, } & \text { I44 }\end{array}$

$\begin{array}{ll}\text { Who knows, but that in every brain may dwell } & 247\end{array}$

Whom does this stately navy bring? I80

$\begin{array}{ll}\text { Why cut you off my boughs, which largely bend } & 226\end{array}$

Why I sit sighing here ask me no more: $\quad$ II5

$\begin{array}{ll}\text { Why must I thus forever be confined } & \text { I33 }\end{array}$

$\begin{array}{ll}\text { With unseen tears and unheard groans } & 290\end{array}$

$\begin{array}{ll}\text { You sons of England whose unquenched flame } & 295\end{array}$ 